\title{
Robotic Spine Surgery: A Preliminary Report
}

\author{
Robotik Omurga Cerrahisi: Ön Klinik Rapor
}

Mehmet Resid ONEN, Mehmet SIMSEK, Sait NADERI

Umraniye Training and Research Hospital, Department of Neurosurgery, Istanbul, Turkey

Corresponding Author: Mehmet Resid ONEN / E-mail: mresit@hotmail.com

\begin{abstract}
AIM: Robotic spine surgery techniques provide reduced pedicle screw malposition and radiation exposure during surgery. The aim of this study is to review clinical and radiological results of robotic spine surgery.

MATERIAL and METHODS: The preoperative, intraoperative and postoperative data for 27 patients were reviewed. To reveal the effect of a learning curve, the cases were divided into two groups: Group A and Group B The clinical data and radiological data were compared with the values obtained from preoperative planning.

RESULTS: The patients consisted of 23 females and 4 males. A total of 136 screws were placed in the 27 cases. The accuracy rate of the screw positions was $98.5 \%$. The overall mean procedure duration was 73.2 minutes for Group A and 46.1 minutes for Group B. The overall mean x-ray exposure time per screw was 1.3 seconds, 1.8 seconds for Group A and 0.9 seconds for Group B. Postoperative imaging revealed that 126 screws were perfect, screw malposition of $<2 \mathrm{~mm}$ was observed for 8 screws, and malposition of $>2 \mathrm{~mm}$ was observed for $2 \mathrm{screws}$.
\end{abstract}

CONCLUSION: Robotic spine surgery provides a high degree of accuracy for pedicle screw placement and allows for reduced radiation exposure.

KEYWORDS: Robotic spine surgery, Pedicle screws, Radiation exposure, Pedicle screws accuracy

öz

AMAÇ: Robotik spinal cerrahi teknikleri pedikül vida malpozisyonu oranlarını ve alınan radyasyon miktarını düşürmüştür. Çalışmanın amacı, robotik spinal cerrahinin klinik ve radyolojik sonuçlarını gözden geçirmektir.

YÖNTEM ve GEREÇLER: Torakolomber stabilizasyon operasyonu yapılan 27 hasta preoperatif, intraoperatif ve postoperatif verileri kaydedildi. Öğrenme eğrisinine göre hastalar; grup A ve grup B olmak üzere ikiye ayrıldı, klinik ve radyolojik veriler, preoperatif ve postoperatif sonuçlarla karşılaştırıldı.

BULGULAR: 23 erkek ve 4 kadından oluşan 27 olguda 136 pedikül vidası yerleştirildi. Vida pozisyon doğruluk oranı \%98,5 idi. Tekniğin genel ortalama süresi 59,2 dakika, grup A'nın süresi 73,2 dakika, grup B'nin süresi 46,1 dakika bulundu. Vida/X-ray maruziyet süresi oranı genel ortalama 1,3 saniye; grup A'da 1,8 saniye, grup B'de 0,9 saniye olarak saptandı. Postoperatif görüntülerde 126 vida mükemmel, sekiz vidada $2 \mathrm{~mm}$ 'den az vida malpozisyonu, iki vidada $2 \mathrm{~mm}$ 'den fazla vida malpozisyonu gözlemlendi.

SONUÇ: Robotik spinal cerrahi pedikül vidalarının yerleştirilmesinde yüksek doğruluk oranları sağlamış, maruz kalınan radyasyon oranını önemli ölçüde düşürmüştür.

ANAHTAR SÖZCÜKLER: Robotik spinal cerrahi, Pedikül vidaları, Radyasyon maruziyeti, Pedikül vidalarının doğruluğu

\section{INTRODUCTION}

Minimally invasive surgery (MIS) has become increasingly popular over the past 20 years. Advances in microsurgery have led to significant developments in spinal and cranial surgical intervention. Percutaneous systems have been developed to implement MIS in patients who have undergone instrumentation during spinal surgery. However, such systems may cause a high degree of radiation exposure for patients and operation room workers. Furthermore, unwanted results may occur because of the reliance on two-dimensional fluoroscopic images during operations $(5,20,26,27)$. Robotic surgical systems were developed to minimize these problems by reducing potential human error and by the use of smaller incisions and minimal amounts of radiation $(12,15,16)$.
The robotic systems used in spine surgery are known as "Robotic Assistant Systems", as opposed to surgical systems in which direct surgery is performed.

Thoracolumbar pedicle screw systems are essential elements in spine surgery and are commonly used in many spinerelated disorders, although complications are possible. Screw malpositions may cause serious complications such as injuries of the root, dural or vascular systems. The rate of screw malposition ranges from $4.9 \%$ to $13.3 \%(2-4,9,13,14,31)$. Such malposition rates tend to be significantly higher in cervical and thoracic spine instrumentation and particularly in cases with spinal deformity. The screw malposition rates may increase to $15.7 \%$ when evaluated with the aid of computerized tomography $(\mathrm{CT})(6,8,17)$. 
To minimize the screw malposition rate, fluoroscopy-based robotic systems were developed. Although more than ten robotic spinal systems have been recognized, there is currently only one robotic system in the spine surgery market. The Renaissance robotic system, which is known as the new generation of the previous SpineAssist robotic system, recently entered the spine surgery market.

We present here the prospective clinical results for patients who underwent a transpedicle screw (TPS) application using a robotic system and an evaluation of the clinical and radiological results.

\section{MATERIAL and METHODS}

We evaluated the results of a prospective study conducted at our clinic on 27 patients who underwent a thoracolumbar stabilization aided by a robotic system during 2012-2013. The patients were assessed in terms of the results obtained from preoperative dynamic radiographs, magnetic resonance imaging (MRI) and CT. Postoperative surgical results were based on CT. Preoperative and postoperative CT was performed according to the Renaissance CT protocol where a lesser dose was administered in the classical CT mode and approximately 12 cGy radiation was applied. Preoperative pedicle locations of TPSs determined in a computer medium

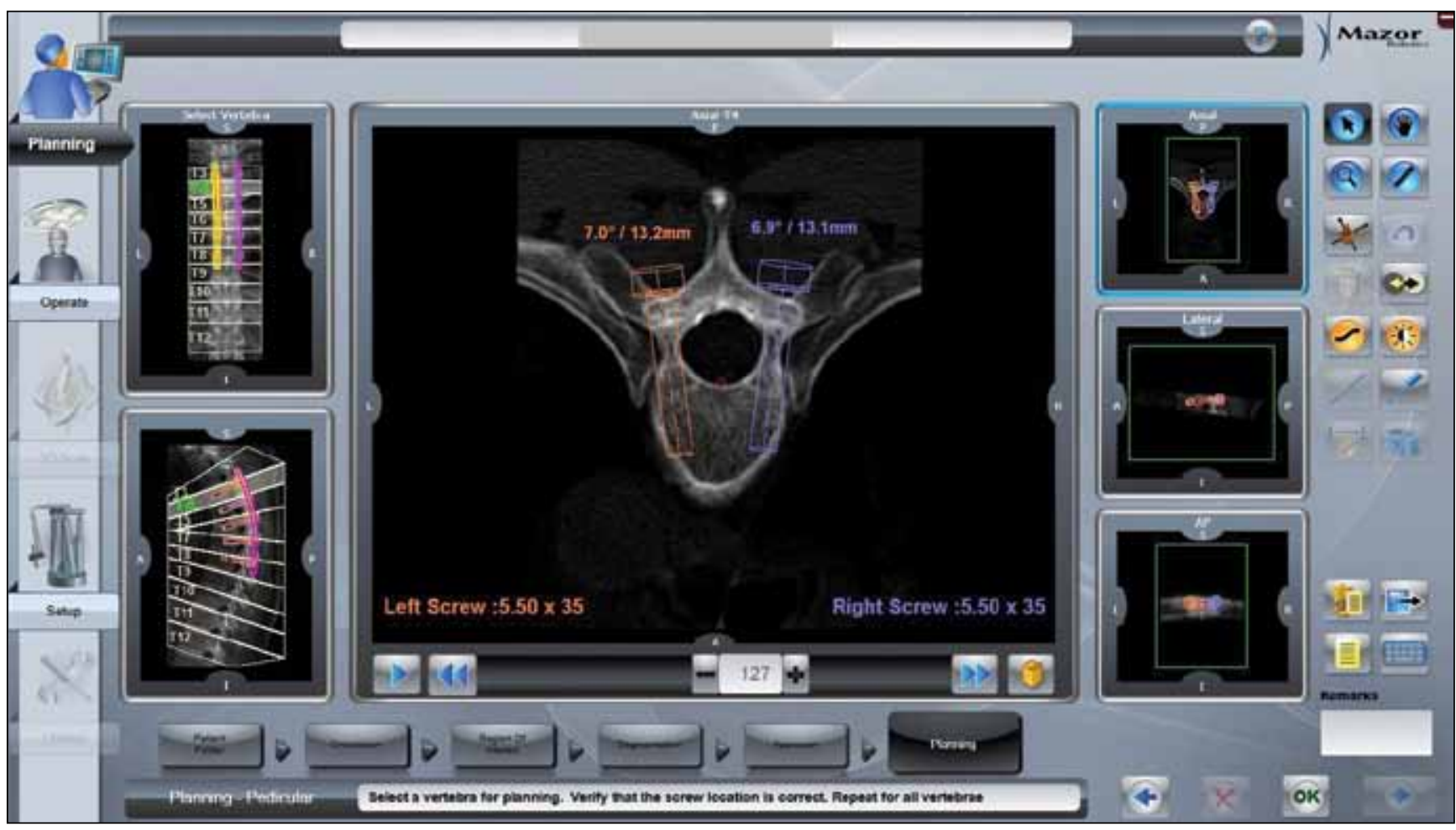

Figure 1: Preoperative planning with the software of Renaissance.

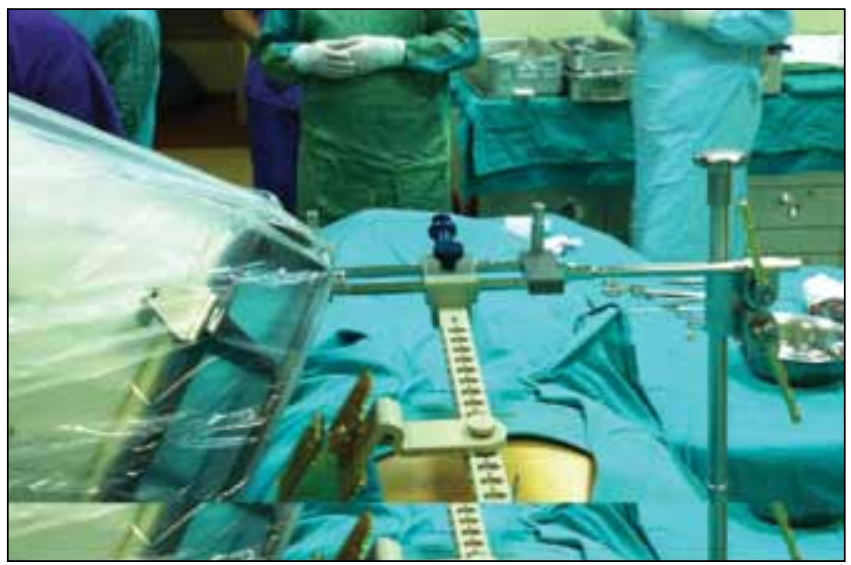

Figure 2: Clamp selection for surgery and registration of clamp position.

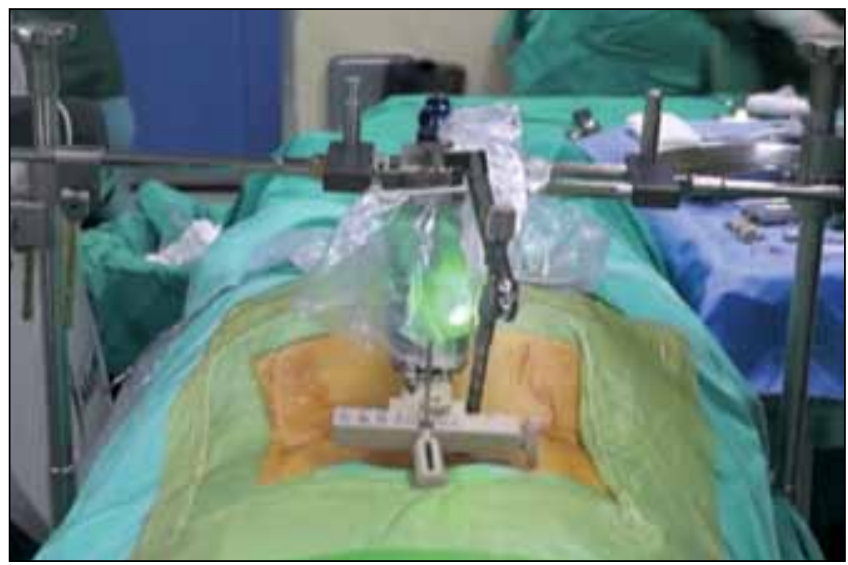

Figure 3: The correct coordinates are received by the robot and $\mathrm{K}$-wires onto this trace. 
were compared with the findings from the postoperative CT. Screw locations in the axial and sagittal planes were classified as described by Gertzbein and Robbins according to the amount of deviation (A: <1 mm, B: 1-2 mm, C: 2-4 mm, D: 4-6 $\mathrm{mm}, \mathrm{E}:>6 \mathrm{~mm})(6)$. Each patient's pain severity was assessed by preoperative and postoperative visual analogue score (VAS).

Mean procedure duration and mean x-ray exposure time was also calculated. Procedure duration (in minutes) was defined as the amount of time between the mounting of the platform to the placement of the screw. X-ray exposure time was defined as the duration (in seconds) of fluoroscopy used from the preoperative robotic recording phase until the end of the surgery.

To reveal the effect of a learning curve, the cases were divided into two groups: Group A (the first 13 cases) and Group B (the last 14 cases).

\section{Phases Monitored During the Surgical Process Aided by the Robotic System}

1. Preoperative planning: Spinal CT images of each patient scheduled to undergo a surgical intervention are loaded onto the robot's software. The CT images must be compatible with the anatomy of the vertebrae and have a cross-sectional interval of $0.4-1.0 \mathrm{~mm}$. The software transforms the loaded CT images into 3D images. The surgeon determines the vertebral segments that will undergo surgical intervention and then selects the type of intervention and the localization, diameter and length of the instruments. The instruments are placed and can be viewed and controlled in great detail in three dimensions in the sagittal, coronal and axial planes. The planning data for the patient are loaded onto the robot, located in the operating room, using portable memory units (Figure 1).

2. Determination of the disposable clamp kit used in surgery: A suitable platform, compatible with percutaneous or open surgery options, is selected. There are many alternative kits manufactured for this purpose, including minimally invasive Hover T, lumbar and thoracic clamp kits.

3. Determination of the clamp position: Preoperative planning information is matched with the intraoperative $x$-ray images to allow the robot to identify the coordinates of the clamp placed in the vertebra in a 3D plane. To facilitate this process, front, rear and oblique $x$-ray images are obtained using a disposable 3D marker installed on the clamp, and the images are loaded onto the robot. The results (including margins of error) are provided to the surgeon. The system accepts and confirms margins of error between 0 and 1 $\mathrm{mm}$. Once the surgeon approves the state, the process may continue (Figure 2).

4. Mounting the robot and motion: The robot is stabilized on a platform placed on the clamp. To increase the stability of the platform during the procedure, a second stabilizer is placed along the spinous process or onto the sacrum. A prompt command is sent to the robot for localization after the operation spot of the surgical intervention is determined. When the robot approaches the correct coordinates, it reports the working tubes that will be used to ensure a correct trace. The surgeon then places the compatible cannula and k-wires along this trace (Figure 3).

5. Manual Procedures: At the end of this phase, the trace determined with the k-wire is drilled and a TPS of predetermined dimensions is inserted.

\section{STATISTICAL ANALYSIS}

Mean values and SDs for all variable parameters were calculated for each group. To test for the significance of the findings, statistical probability ( $P$ value) for each comparison between the groups was calculated through the 2-sample (heteroscedastic), 1-tail t test method. Within the study group, outcome measures were also compared between group $A$ and group $B$. The significance level was set at $P$ value less than 0.05 .

\section{FINDINGS}

Of the 27 patients who underwent TPS with the aid of the robotic system, 4 (14.8\%) were male and 23 (85.2\%) were female. The age range of the patients was 36-72 (average: 55). Of the 27 patients, $13(48.1 \%)$ were diagnosed with spondylolisthesis, $5(18.5 \%)$ had a vertebral fracture and 9 (33.3\%) had a degenerative lumbar stenosis. Sixty-two screws (45.6\%) were implanted in Group A, and 74 screws $(54.4 \%)$ were implanted in Group B. Application of a TPS by an open surgery process was performed in 16 (59.2\%) patients, and percutaneous intervention was performed in 11 (40.8\%) patients. The mean BMI value of the patients was 30.89 (range: 24.1-43.2). A total of 136 TPS interventions were applied to the patients. Fourteen (10.2\%) of the TPSs were placed in the thoracic vertebrae, $110(81.0 \%)$ in the lumbar vertebrae and $12(8.8 \%)$ in the sacrum of the patients (Table I).

The mean duration of the procedure was 59.2 minutes. The mean value of this duration was 73.2 minutes for the Group A patients and 46.1 minutes for the Group B patients. The mean duration of the procedure per screw was 15.5 minutes for the Group A patients and 8.6 minutes for the Group B patients $(p<0.05)$ (Table II).

The mean duration of the $\mathrm{x}$-Ray exposure time per screw was 1.8 second for the Group A patients and 0.9 second for the Group B patients. The overall mean duration of the $x$-ray exposure time per screw was 1.3 second $(p<0.05)$ (Table II).

A comparison of the findings of the preoperative planning $\mathrm{CT}$ and those of the postoperative $\mathrm{CT}$ revealed a perfect screw position for 124 screws. Screw malposition of $<2 \mathrm{~mm}$ was observed for 10 screws, and malposition of $>2 \mathrm{~mm}$ was observed for two screws. No neural or vascular damage was observed in the patients, and revisions were not performed due to the malposition of the screws. 


\section{DISCUSSION}

The reliability of the SpineAssist robotic system was confirmed by the FDA in 2004. The SpineAssist robotic system was used on more than 2000 patients in more than 25 centers from 2005 to 2011 (4). The reason for using this robotic system is to achieve the most reliable and non-erroneous route for pedicle screws and to minimize the rate of radiation exposure during the operation.

All of the SpineAssist cases that were performed from 2005 to 2009 were studied retrospectively by Devito et al. This study included data from 673 patients, $88 \%$ of whom were treated with pedicle screws, $10 \%$ with vertebroplasty and $2 \%$ with biopsy. A total of 3271 pedicle screws were placed with the aid of the SpineAssist system (4).

In the study by Devito et al., the cases were assessed in terms of the compatibility of preoperative and postoperative CT images of TPSs. In this study, $89.3 \%$ of screws were positioned consistently with the planning phase, whereas a deviation of $>2 \mathrm{~mm}$ was found in only $2.4 \%$ of the screws. Transient neurological deficits were observed in $0.7 \%$ of the patients. The screw malposition rate using the robotic system is lower than the deviation rates using freehand, which was reported to be $5.3-8.3 \%(1,11,16)$.

The Renaissance robotic system used in the present study is a second-generation SpineAssist robotic system, which was released to the market in June 2011. The new software has a higher sensitivity in the positioning process, and the transaction capacity is ten-fold faster. The software is compatible with PACS and intraoperative imaging systems. With the new system, a 3D model can be obtained by a 15 -second scanning process from the exit of the 2D C-arm. The current robotic system is specially designed for surgical interventions of the thoracic and lumbar vertebrae and for use in the spinal instrumentation process and vertebral reinforcement (19).

Because of the preoperative and intraoperative preparation phases during robotic spine surgery, robotics-assisted instrumentation takes more time in comparison with conventional approaches. However, the total surgical

Table I: Distributions of the Applied TPS Levels

\begin{tabular}{l|l|c|c|c|} 
& & Group A & Group B & Total \\
\hline \multirow{3}{*}{ Level } & Thoracic & 6 & 8 & $14(10.2 \%)$ \\
\cline { 2 - 4 } & Lumbar & 48 & 62 & $110(81.0 \%)$ \\
\cline { 2 - 4 } & Sacral & 8 & 4 & $12(8.8 \%)$
\end{tabular}

duration of the process in patients who undergo multi-level instrumentation is reduced because of the decrease in the period typically lost during $x$-ray control and determination of screw location. The superiority of the system is evident in percutaneous interventions, in patients who undergo deformity surgery and in cases of recurrence $(10,11,33)$. In our study, the mean surgical duration was 46.1 minutes in Group A patients as opposed to 73.2 minutes in Group B patients. As our experience with the robotic system increases, the shortening of the duration lost during the registration period will facilitate the process. Other important factors that determine the duration of robotic surgery are the BMI value of patients and the levels of segments that are subject to surgical intervention. X-ray imaging in the instrumentation process of the upper thoracic region is particularly difficult in obese patients with high BMI values and may complicate registration $(1,11,15)$.

There have only been a few studies of robotic spine surgeries. These studies have reported groups with different disorders, instrumentation results, whether screws were placed correctly and deviation ratios. A review of the robotic instrumentation showed that there was $99 \%$ accuracy in screw placement and minor deviations in $1 \%$ of cases. No neurological or vascular damage was observed $(11,28)$ (Table III).

In our study, the accuracy rate of pedicle screw positioning was found to be $98.5 \%$. This rate includes the total number of accurate placements and those that were malpositioned by less than $2 \mathrm{~mm}$. Two screws placed at level T8 in one patient showed $2.1 \mathrm{~mm}$ deviations. No neurological, vascular or dural damage was observed in the patients. It is of note that the location of the k-wire for these cases was consistent with the preoperative planning. Malposition in these two screws was due to the use of normal screws instead of cannulated screws, resulting in forcing of the pedicle and vertebral body wall due to the reduction in tolerance because the thickness of the pedicle was $<2 \mathrm{~mm}$. This patient was the third case operated by a robotic system. An increase in the number of such operations may reduce the possibility of errors (Figure $4 A, B$ ).

In patients in whom surgery using a robotic system is planned, problems may occur during the recording phase in particular. High BMI values of patients may affect preoperative descriptions in relation to the technical issues of fluoroscopy. Although we had planned robotic surgery for two of our patients in addition to the 27 patients reviewed in this study, these two patients were operated by conventional methods due to a failure of the registration between the preoperative $x$-ray images and the robotic software. We were unable to perform the recording process of the upper thoracic region

Table II: Mean Duration of the Procedure (MDP), MDP Per Screw, and x-Ray Exposure Time (MXET) Per Screw

\begin{tabular}{|l|c|c|c|c|}
\hline & Group A & Group B & Total & Significance \\
\hline MDP (minute) & 73.2 & 46.1 & 59.2 & $\mathrm{p}<0.05$ \\
\hline MDP per screw (minute) & 15.5 & 8.6 & 11.8 & $\mathrm{p}<0.05$ \\
\hline MXETS per screw (second) & 1.8 & 0.9 & 1.3 & $\mathrm{p}<0.05$ \\
\hline
\end{tabular}


Table III: Reports on the Use of the Renaissance and SpineAssist Spine Surgery Robotic Systems

\begin{tabular}{|c|c|c|c|c|c|}
\hline Author & System & Application & $\begin{array}{l}\text { Percutaneous/ } \\
\text { Open }\end{array}$ & $\begin{array}{l}\text { Number of } \\
\text { Patients }\end{array}$ & Comments \\
\hline $\begin{array}{l}\text { Sukovicz W } \\
(2006)(30)\end{array}$ & SpineAssist & TPS & Not stated & 14 & $93 \%$ successful \\
\hline $\begin{array}{l}\text { Barzilay Y } \\
(2006)(1)\end{array}$ & SpineAssist & TPS & $0 / 9$ & 9 & $\begin{array}{l}\text { Software- and patient-induced } \\
\text { technical problems were } \\
\text { encountered in } 4 \text { patients }\end{array}$ \\
\hline $\begin{array}{l}\text { Pechlivanis I (2009) } \\
(23)\end{array}$ & SpineAssist & TPS & $31 / 31$ & 31 & $93.5 \%$ successful \\
\hline $\begin{array}{l}\text { Kantelhard SR } \\
(2011)(11)\end{array}$ & SpineAssist & TPS & $35 / 20$ & 55 & $\begin{array}{l}94.5 \% \text { successful, } 55 \% \text { decrease in } \\
\text { using } x \text {-ray }\end{array}$ \\
\hline Zaulan Y (33) & SpineAssist & VP & 23 & 23 & $\begin{array}{l}65 \% \text { decrease in using } \\
\text { fluoroscopy }\end{array}$ \\
\hline $\mathrm{Hu} X(2012)(10)$ & Renaissance & TPS & $16 / 96$ & 102 & $98.9 \%$ successful \\
\hline Roser (2013) (25) & SpineAssist & TPS & $30 / 46$ & 46 & $\begin{array}{l}\text { Surgical comparison performed } \\
\text { by Freehand and navigation: } \\
40 \% \text { decrease in radiation, } 99 \% \\
\text { accuracy in screws }\end{array}$ \\
\hline Togawa (2007) (32) & SpineAssist & $\begin{array}{l}\text { TPS- } \\
\text { translaminar } \\
\text { screw }\end{array}$ & $\begin{array}{l}24 \text { percutaneous, } \\
43 \text { screw, } 19 \text { level } \\
\text { percutaneous } \\
\text { translaminar }\end{array}$ & 10 cadavers & $\begin{array}{l}\text { TPS } 95.3 \% \text { in cadaver study, } 100 \% \\
\text { success in translaminar, excluding } \\
\text { two levels where the k-wire was } \\
\text { broken }\end{array}$ \\
\hline
\end{tabular}
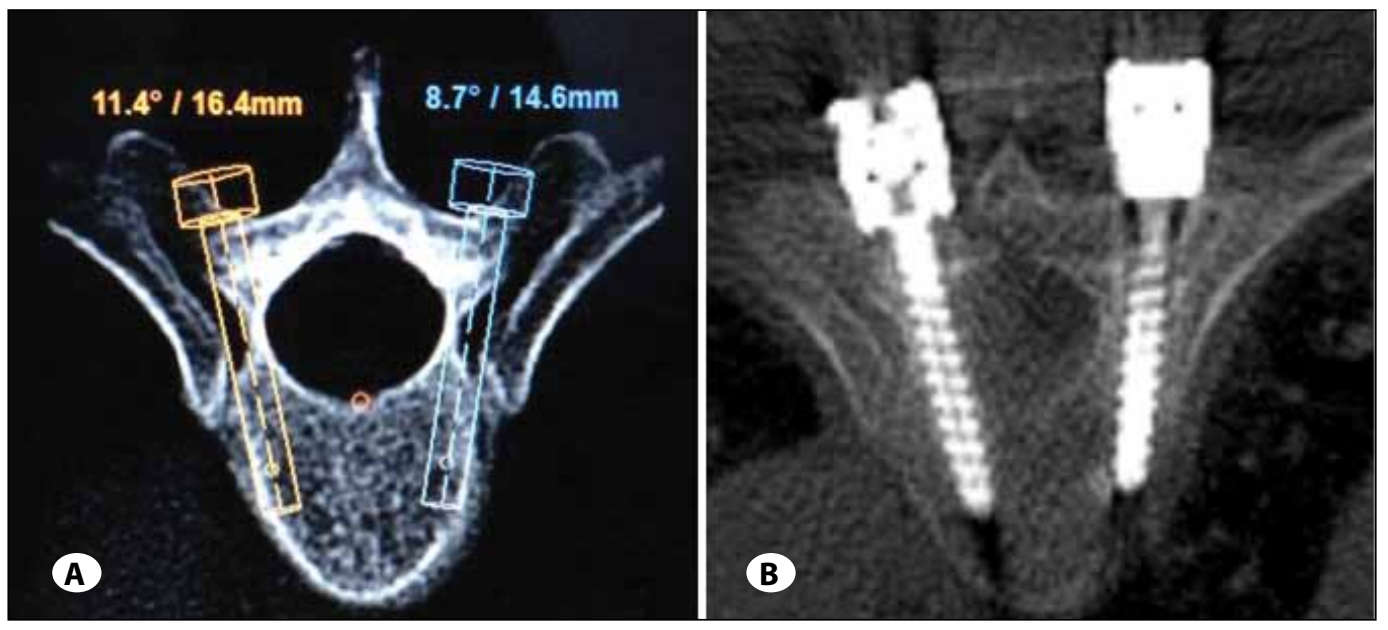

Figure 4: Two screws placed at level T8 in one patient showed $2.1 \mathrm{~mm}$ deviations.

A) Preoperative planning, B) Postoperative imaging with $\mathrm{CT}$.

(T2-T5) for one of the patients because the fluoroscopic images did not have the necessary quality; for the other patient, the cause was due to advanced obesity (BMI 47.3). Similar problems were encountered in other studies for the same reasons $(1,15)$.

\section{Radiation Exposure}

Radiation exposure of workers in the operating room is a major problem in spinal surgery using pedicle screw systems. Factors such as the experience of the surgeon, his/her working style and the type and level of the pathology may increase or decrease the number of fluoroscopies. The use of fluoroscopy may dramatically increase in patients diagnosed with scoliosis or with advanced degenerative variation. Recent studies have demonstrated significant increases in malignancy rates caused by exposure to X-ray radiation in surgeons who perform orthopedic, urological or neurosurgery procedures $(7,18,21,22,29)$. In spite of the reductions in the risk of radiation exposure by the use of lead-containing vests and lead panels in the operating room, the risk can never be reduced to zero. Robot-assisted spine surgery may greatly reduce the use of fluoroscopy. 
Patients are exposed to a total of 25 mrem of radiation during a standard lung graph, 500 mrem during a hip graph and 1200-4000 $\mathrm{mrem} / \mathrm{min}$ during a C-arm fluoroscopy. In view of the recommended annual limit of 2000-5000 mrem radiation, it is clearly important to consider the radiation exposure of workers in the operating room (29).

AP and oblique graphs obtained during the preoperative planning phase of robotic spine surgery are sufficient for a typical patient. After the planning phase, extra images can be obtained to confirm the reliability of the procedure or at the request of the surgeon. On the other hand, the radiation dosage applied according to the BMI values of the patients during the surgery may vary $(15,24,25,29)$. In the current study, the $x$-Ray exposure time was 1.8 second/screw for Group A patients, 0.9 second/screw for Group B patients and $1.3 \mathrm{sec} /$ screw overall. In a study using classical c-arm fluoroscopy in a cadaver model, Lieberman et al. demonstrated that the use of fluoroscopy was reduced by $98.2 \%$ in comparison with classical percutaneous TPS and robot supportive TRP interventions; a mean value of 0.7 second/screw was obtained (16). In a study of 101 patients who underwent operations using the same robotic system, Hu et al. reported a significant decrease in the use of fluoroscopy, particularly in percutaneous patients. Three studies using the previous generation SpineAssist system reported a 55-65\% reduction in the use of fluoroscopy $(11,15,25)$.

In percutaneous instrumentation, the localization and orientation of screws are completely dependent on fluoroscopy. Robotic supported systems, therefore, have significant advantages. In contrast to open surgery, the incision in percutaneous interventions is applied only when the trace is compatible with the cannula. The possibility of malposition may increase as the angle of the cannula changes because of the surrounding soft tissues. Robotic systems also appear to provide significant advantages for instrumentation in cases with spinal deformities.

Although robotic surgery has many advantages, there are some problems associated with robotic systems. The 3D markers that are placed on the platform and used during the preoperative recording phase are large and may, therefore, cause difficulties in obtaining the most appropriate images by fluoroscopy. The apparatus placed during the oblique imaging phase is relatively short. It may be necessary to use lengthening apparatuses called extensions in slightly obese patients. These apparatuses may cause difficulties during the imaging phase and during installation of the platform.

In conclusion, robotic spine surgery techniques have expanded the horizon of spine surgery. The major advantages of this new technology include greater reliability in screw placement and reduced radiation exposure.

\section{REFERENCES}

1. Barzilay $Y$, Liebergall $M$, Fridlander A, Knoller N: Miniature robotic guidance for spine surgery-introduction of a novel system and analysis of challenges encountered during the clinical development phase at two spine centres. Int J Med Robot 2:146-153, 2006

2. Burch S: Surgical complications of spinal deformity surgery. Neurosurg Clin N Am 18:385-392, 2007

3. Davne SH, Myers DL: Complications of lumbar spinal fusion with transpedicular instrumentation. Spine 17:184 -189, 1992

4. Devito DP, Kaplan L, Dietl R, Pfeiffer M, Horne D, Silberstein B, Hardenbrook M, Kiriyanthan G, Barzilay Y, Bruskin A, Sackerer $D$, Alexandrovsky V, Stüer C, Burger R, Maeurer J, Donald GD, Schoenmayr R, Friedlander A, Knoller N, Schmieder K, Pechlivanis I, Kim IS, Meyer B, Shoham M: Clinical acceptance and accuracy assessment of spinal implants guided with spine assist surgical robot. Spine 35:2109-2115,2010

5. Fransen P: Fluoroscopic exposure in modern spinal surgery. Acta Orthop Belg 77:386-389, 2011

6. Gertzbein SD, Robbins SE: Accuracy of pedicular screw placement in vivo. Spine 15:11-14, 1990

7. Gundestrup M, Storm HH: Radiationinduced acute myeloid leukaemia and other cancers in commercial jet cockpit crew: Apopulation-based cohort study. Lancet 354:2029-2031, 1999

8. Hicks JM, Singla A, Shen FH, Arlet V: Complications of pedicle screw fixation in scoliosis surgery a systematic review. Spine $35: 465-470,2010$

9. Holly LT, Foley KT: Three-dimensional fluoroscopy-guided percutaneous thoracolumbar pedicle screw placement. Technical note. J Neurosurg 99: 324 -329, 2003

10. Hu X, Ohnmeiss DD, Lieberman IH: Robotic-assisted pedicle screw placement: Lessons learned from the first 102 patients. Eur Spine J 22: 661-666, 2013

11. Kantelhardt SR, Martinez R, Baerwinkel S, Burger R, Giese A, Rohde V: Perioperative course and accuracy of screw positioning in conventional, open robotic-guided and percutane- ous robotic-guided, pedicle screw placement. Eur Spine J 20:860-868, 2011

12. Kaplan L: Robotic assisted vertebral cement augmentation: A major radiation reduction tool. Presented at: Aging Spine Symposium, March. Jerusalem, Israel, 2011

13. Klein SA, Glassman SD, Dimar JR 2nd, Voor MJ: Evaluation of the fixation and strength of a "rescue" revision pedicle screw. J Spinal Disord Tech 15: 100-104, 2002

14. Kosmopoulos V, Schizas C: Pedicle screw placement accuracy: A metaanalysis. Spine 32:111-120, 2007

15. Lieberman IH, Hardenbrook M, Wang JC, Guyer R, Khanna: A Radiation exposure using miniature robotic guidance for spinal surgery. Spine J 7:160-163, 2007

16. Lieberman IH, Hardenbrook MA, Wang JC, Guyer RD: Assessment of pedicle screw placement accuracy, procedure time, and radiation exposure using a miniature robotic guidance system. J Spinal disorder Tech 25:241-248, 2012 
17. Lonstein JE, Denis F, Perra JH, Pinto MR, Smith MD, Winter RB: Complications associated with pedicle screws. J Bone Joint Surg 81:1519-1528, 1999

18. Mastrangelo G, Fedeli U, Fadda E, Giovanazzi A, Scoizzato $\mathrm{L}$ : Increased cancer risk among surgeons in an orthopaedic hospital. Occupational Medicine 55:498-500, 2005

19. Mazor Robotics Introduces Renaissance (MKC0067-01-A); http://www.mazorrobotics.com/int/renaissance-int/c-onsite. html

20. McAfee PC, Phillips FM, Andersson G, Buvenenadran A, Kim CW, Lauryssen C, Isaacs RE, Youssef JA, Brodke DS, Cappuccino A, Akbarnia BA, Mundis GM, Smith WD, Uribe JS, Garfin S, Allen RT, Rodgers WB, Pimenta L, Taylor W: Minimally invasive spine surgery. Spine, 35: 271-273, 2010

21. Mehlman CT, DiPasquale TG: Radiation exposure to the orthopaedic surgical team during fluoroscopy: How far away is far enough? J Orthop Trauma 11:392-398, 1997

22. Norris TG: Radiation safety in fluoroscopy. Radiol Technol 73:511-533, 2002

23. Pechlivanis I, Kiriyanthan G, Engelhardt M, Scholz M, Lücke S, Harders A, Schmieder K: Percutaneous placement of pedicle screws in the lumbar spine using a bone mounted miniature robotic system first experiences and accuracy of screw placement. Spine 34:392-398, 2002

24. Rampersaud YR, Justin HT, Salonen D, Farooq S: Clinical accuracy of fluoroscopic computer-assisted pedicle screw fixation: A CT analysis. Spine 30:183-190, 2005

25. Roser F, Tatagiba M, Maier G: Spinal robotics: Current applications and future perpectives. Neurosurgery 72:12-18, 2013
26. Samartzis D, Dip E, Shen FH, Perez-Cruet MJ, Anderson G: Minimally invasive spine surgery: A historical perspective. Orthop Clin N Am 38:305-326, 2007

27. Schizas C, Michel J, Kosmopoulos V, Theumann N: Computer tomography assessment of pedicle screw insertion in percutaneous posterior transpedicular stabilization. Eur Spine J 16:613-617, 2007

28. Shoham M, Lieberman IH, Benzel EC, Togawa D, Zehavi E, Zilberstein B, Roffman M, Bruskin A, Fridlander A, Joskowicz L, Brink-Danan S, Knoller N: Robotic assisted spinal surgeryfrom concept to clinical practice. Comput Aided Surg 12: 105-115, 2007

29. Singer G: Occupational radiation exposure to the surgeon.JJ Am Acad Orthop Surg 13(1):69-76, 2005

30. Sukovich W, Brink-Danan S, Hardenbrook M: Miniature robotic guidance for pedicle screw placement in posterior spinal fusion: Early clinical experience with the Spine Assist. J Med Robotics Comput Assist Surg 2: 114-122, 2006

31. Tian NF, Huang QS, Zhou P, Zhou Y, Wu RK, Lou Y, Xu HZ. Pedicle screw insertion accuracy with different assisted methods: A systematic review and meta-analysis of comparative studies. Eur Spine J 20:846-859, 2011

32. Togawa D, Kayanja MM, Reinhardt MK, Shoham M, Balter A, Friedlander A, Knoller N, Benzel EC, Lieberman IH: Bonemounted miniature robotic guidance for pedicle screw and translaminar facet screw placement: Part 2-evaluation of system accurac. Neurosurgery 60:129-138, 2007

33. Zaulan Y, Alexandrovsky V, Khazin F, Silberstein B, Shoham M, Roffman M, Bruskin A: Robotic assisted vertebroplasty: Our experience with a novel approach to the treatment of vertebral compression fractures. Surgery 140: 124-125, 2009 